International Journal of

Environmental Research and

Public Health

ISSN 1660-4601

www.mdpi.com/journal/ijerph

Article

\title{
A Comparative Land Use-Based Analysis of Noise Pollution Levels in Selected Urban Centers of Nigeria
}

\section{David O. Baloye ${ }^{.1,2, *}$ and Lobina G. Palamuleni ${ }^{1, \dagger}$}

1 Department of Geography and Environmental Sciences, North West University, Mafikeng Campus, Private Bag X2046, Mmabatho, 2735, South Africa; E-Mail: Lobina.Palamuleni@nwu.ac.za

$\dagger$ This author contributed equally to this work.

* Author to whom correspondence should be addressed; E-Mail: 27335550@nwu.ac.za; Tel.: +27-623-980-869.

Academic Editor: Paul B. Tchounwou

Received: 14 July 2015 / Accepted: 8 September 2015 / Published: 29 September 2015

\begin{abstract}
Growth in the commercialization, mobility and urbanization of human settlements across the globe has greatly exposed world urban population to potentially harmful noise levels. The situation is more disturbing in developing countries like Nigeria, where there are no sacrosanct noise laws and regulations. This study characterized noise pollution levels in Ibadan and Ile-Ife, two urban areas of Southwestern Nigeria that have experienced significant increases in population and land use activities. Eight hundred noise measurements, taken at 20 different positions in the morning, afternoon, and evening of carefully selected weekdays, in each urban area, were used for this study. Findings put the average noise levels in the urban centers at between $53 \mathrm{~dB}(\mathrm{~A})$ and $89 \mathrm{~dB}(\mathrm{~A})$, a far cry from the World Health Organization (WHO) permissible limits in all the land use types, with highest noise pollution levels recorded for transportation, commercial, residential and educational land use types. The result of the one-way ANOVA test carried out on the dependent variable noise and fixed factor land use types reveals a statistically significant mean noise levels across the study area $(\mathrm{F}(3,34)=15.13, p=0.000)$. The study underscores noise pollution monitoring and the urgent need to control urban noise pollution with appropriate and effective policies.
\end{abstract}


Keywords: noise pollution; land use; developing countries; urbanization; cities; Nigeria

\section{Introduction}

One of the environments most influenced by man are urban settlements [1-4]. Evolving from the primitive settlements that existed thousands of years ago, and which were characterized by crude technology meant only for feeding, sheltering, clothing, and survival, urban settlements have grown into contemporary, highly complex, and interwoven existing societies, such as towns, cities, and mega cities, which are largely driven by sophisticated technologies developed to provide, not only basic human needs, but also services than run the day-to-day, diversified socio-economic and political activities of modern man $[3,5]$. The process of this incremental growth and complexity in world urban settlements has been institutionally referred to as urbanization.

Existing as an obvious process with subtle propagation, urbanization brings about social, cultural, economic, political, and ecological changes in the human settlement landscape. Although lacking any consensual definition, urbanization has been described as a culmination of factors resulting in processes that cause marked and persistent modifications in land-use activities and interactions; thereby resulting in population explosion, spatial expansion as well as political and service complexity [6-8]. These changes have not been without negative consequences, some of which have become issues in global human development and sustainability. For instance, urbanization has been associated with the precarious rise in energy consumption and global climate change [7,9-12], degrading urban ecology [13-19], urban land degradation and increased disaster rate [20-25], profound cultural change and infiltration [26-28], as well as extreme generation of hazardous waste [29-32], among others.

One of the most dangerous negative effects of urbanization is pollution, described as the introduction or presence of potentially damaging contaminants into the environment, thereby having a negative effects on lives in the affected areas [33,34]. In most cases, the sources of pollution are direct or otherwise by-products of the quickly increasing and divergent, environment-destroying activities of man. While some forms of pollution, such as water [35-37], air [38-41], land [22,42], and soil pollution [24,43-45] are more obvious and have generated a great deal of research interest across the globe, and especially in developing countries, noise, as a major pollution in contemporary urban settlements of developing countries, has not been given necessary attention.

The definition of noise has been widely contested owing to the subjectivity of the concept. To a large extent, noise is determined by the physical and emotional frame of the person or people exposed to it. This subjectivity was described by Job [46] as noise sensitivity, which affects the internal states, including physiological, psychological, and attitudinal makeup of individuals, which increases their degree of reactivity to noise. This suggests that noise reflects certain interrelationships between the attitudes of a person, the desire for its control through standards, and the characteristics of the physical stimulus of each type of sound. This further shows that the basic line of demarcation between sound and noise is that, while the former is a sensory perception, the latter corresponds to undesired and displeasing sound [47]. Generally, therefore, noise has been defined as sound made out of place [48].

This presupposes that noise pollution can be described as any form of noise, usually resulting from man's activities, and that has either a prolonged or short duration but is perceived by the hearers as 
disturbing, and also has the potential of causing short- or long-term negative effects on the affected person's complete state of wellbeing [48-52]. In addition to creating a nuisance to the urban environment, noise pollution has been associated with psychological [53-55], physiological [56-58], and physical effects on exposed populations [59-61]. In specific terms, deafness, tinnitus, cardiac problems, such as hypertension ischemic heart disease and vasoconstriction, sleep interferences, headaches, fatigue, stomach ulcers, vertigo, and aggression have been attributed to noise pollution $[62,63]$.

Sensitivity of the human ear to sounds at different frequencies, measured by the A-weighted decibel scale with $0 \mathrm{~dB}(\mathrm{~A})$, for normal conversation has been put at between $45 \mathrm{~dB}(\mathrm{~A})$ and $60 \mathrm{~dB}(\mathrm{~A})$ when people are within three to six feet apart. This translates roughly to the lowest threshold of human hearing. Exposure to levels higher than $80 \mathrm{~dB}(\mathrm{~A})$ for a prolonged period has been found to be deafening, while sound levels between 130 and $140 \mathrm{~dB}(\mathrm{~A})$ are described as pain [64]. Over the years, these noise limits have been greatly exceeded in many urban settlements of developing countries. Nevertheless, some developed countries, such as the United States of America, Australia, and Japan, and organizations such as the World Health Organization (WHO) have set standards of noise pollution emanating from different land uses, both in the day and night (Tables 1 and 2). Unlike the achievement made in noise control in many developed countries, existing noise regulations in Nigeria, as in many other developing countries, have not been effective.

Table 1. A-weighted noise level standards in selected countries of the world [65].

\begin{tabular}{ccccccccc}
\hline \multirow{2}{*}{ Countries } & \multicolumn{2}{c}{ Industrial } & \multicolumn{2}{c}{ Commercial } & \multicolumn{2}{c}{ Residential } & \multicolumn{2}{c}{ Silent Zones } \\
& Day & Night & Day & Night & Day & Night & Day & Night \\
\hline Australia (dB) & 55 & 55 & 55 & 45 & 45 & 35 & 45 & 35 \\
India (dB) & 75 & 70 & 65 & 55 & 55 & 45 & 50 & 40 \\
Japan (dB) & 60 & 50 & 60 & 50 & 50 & 40 & 45 & 35 \\
US, EPA (dB) & 70 & 60 & 60 & 50 & 55 & 45 & 45 & 35 \\
WHO (dB) & & & & & & & & \\
(WHO 2009, [66]) & & & & & & & & \\
\hline
\end{tabular}

In Nigeria, the absence of noise to many urban dwellers, is perceived as a strange thing, only typical of the rural areas of the country. This may partly be attributed to the absence of enforced legislation aimed at correcting the negative effect of urbanization, in addition to the unavailability of sufficient theoretical and applied information-driven knowledge about noise pollution in the country. Although several studies have been conducted in respect to noise pollution in Nigeria, most of them have focused on the health and socio-economic effects of noise pollution [67-77]. Noise pollution has a tendency of exacerbating already degenerated urban settlements in the country. The current study sought to quantify the magnitude and level of noise pollution associated with different land uses in the Ibadan and Ile-Ife urban settlements in Southwestern Nigeria. Characterization of noise levels across the study areas was achieved by using Geographical Information Systems (GIS) to map out noise risk exposure, compare ambient noise levels, and evaluate the relationship between land use and urban noise level. 


\section{Experimental Section}

\subsection{Description of the Study Area}

The study areas for this paper are Ibadan, located between latitudes $7^{\circ} 18^{\prime \prime} \mathrm{N}$ and $7^{\circ} 27^{\prime \prime} \mathrm{N}$ and longitudes $3^{\circ} 50^{\prime \prime} \mathrm{E}$ and $3^{\circ} 58^{\prime \prime} \mathrm{E}$; and Ile-Ife located between latitudes $7^{\circ} 28^{\prime} \mathrm{N}$ and $7^{\circ} 32^{\prime} \mathrm{N}$ and longitudes $4^{\circ} 28^{\prime} \mathrm{E}$ and $4^{\circ} 34^{\prime} \mathrm{E}$. Ibadan, the third largest city in Africa, with an average population of about 2,550,593, and an average population density of 828 persons per $\mathrm{km}^{2}$ [78] and Ile-Ife, with a projected population of 501,952 [79], are both located contiguously within the same geopolitical zone of the southwestern states of Oyo and Osun, respectively. The two cities also share similar historical developments, as they were both prominent indigenous Yoruba cities that developed outwardly from the Oba's palace. Similarly, both cities have served as administrative centers at different periods of development of Nigeria. Figure 1 and Figure 2 show metropolitan areas of Ibadan and Ile-Ife, respectively. Climatically, both cities fall under the tropical wet and dry climates (Koppen climate classification, Aw), with a lengthy wet season, which runs from March to October, and relatively constant temperatures throughout the year, between $23{ }^{\circ} \mathrm{C}$ and $33{ }^{\circ} \mathrm{C}$ during the dry season. At the moment, both Ibadan and Ile-Ife are expressing fast growth, both spatially and socio-economically. The presence of Nigeria's foremost universities, the University of Ibadan and Obafemi Awolowo in Ibadan and Ile-Ife, respectively, has in no small way contributed to the growth and development of the two study areas. This is evident in the development of residential, commercial, and other socio-economic activities in the areas adjoined to the university campuses.

\subsection{Datasets and Sources}

Datasets for this study were obtained through primary sources and they include noise level measurements, acquired with an android mobile phone. The mobile phone was equipped with a noise meter, which was calibrated with a digital noise meter, SET 1350, with a measuring level range of 35-130 dB(A). A Global Positioning System (GPS) handheld receiver was used to obtain positional details of the noise sample stations in both Ibadan metropolis and urban Ile-Ife as shown in Figure 1 and Figure 2 respectively. The noise measurements were randomly taken at street level around the different land-use types in the study areas, including road junctions, market centers, bus parks, and residential areas. Specifically, these land uses were classified as transportation, commercial, industrial, educational, or residential.

The observations were made by standing at a location at a time, with the instrument pointing, in most cases, at any convenient direction and not at any specific noise source. This was to ensure that the general ambient noise levels were recorded and not the sound of a particular object or source of sound. A-weighted instantaneous sound pressure level measurements were recorded at intervals of $30 \mathrm{~s}$ for $10 \mathrm{~min}$. The average of this was then obtained, thereby making 20 noise readings per sampled location. This procedure was carried out for morning (7:00-9:00 a.m.), afternoon (12:00-2:00 p.m.), and evening (5:00-7:00 p.m.) periods, on Monday, Wednesday, Friday, Saturday, and Sunday. These days of the week were purposefully picked for the following reasons: Monday was chosen because it is the first working day of the week, when those that may have travelled for the weekend are returning to the cities; Wednesday was included to typify working days not associated with the usual rush in and out of the 
study areas on Mondays and Fridays; Friday was included because it is the last working day of the week, when people may want to leave the cities, and when some social events are organized; Saturday, was selected because it is the usual day for shopping and many other social functions; and Sunday, because of the religious activities associated with it. Tuesday and Thursday were left out because, in most cases, they share the characteristics of Wednesdays as mid-week days.

Working with noise level measurement it is important to note that, because of the logarithmic nature of the decibel unit, sound levels cannot be arithmetically added or subtracted, and are somewhat cumbersome to handle mathematically. However, basic rules apply when dealing with sound levels. First, if a sound's intensity is doubled, the sound level increases by $3 \mathrm{~dB}$, regardless of the initial sound level. For instance, $60 \mathrm{~dB}+60 \mathrm{~dB}=63 \mathrm{~dB}$. Second, the total sound level produced by two sounds of different levels is usually only slightly more than the higher of the two. For instance, $60.0 \mathrm{~dB}+70.0 \mathrm{~dB}=70.4 \mathrm{~dB}$ [79]. Hence, for this study, noise levels were recorded based on Finegold et al. assumptions [80].

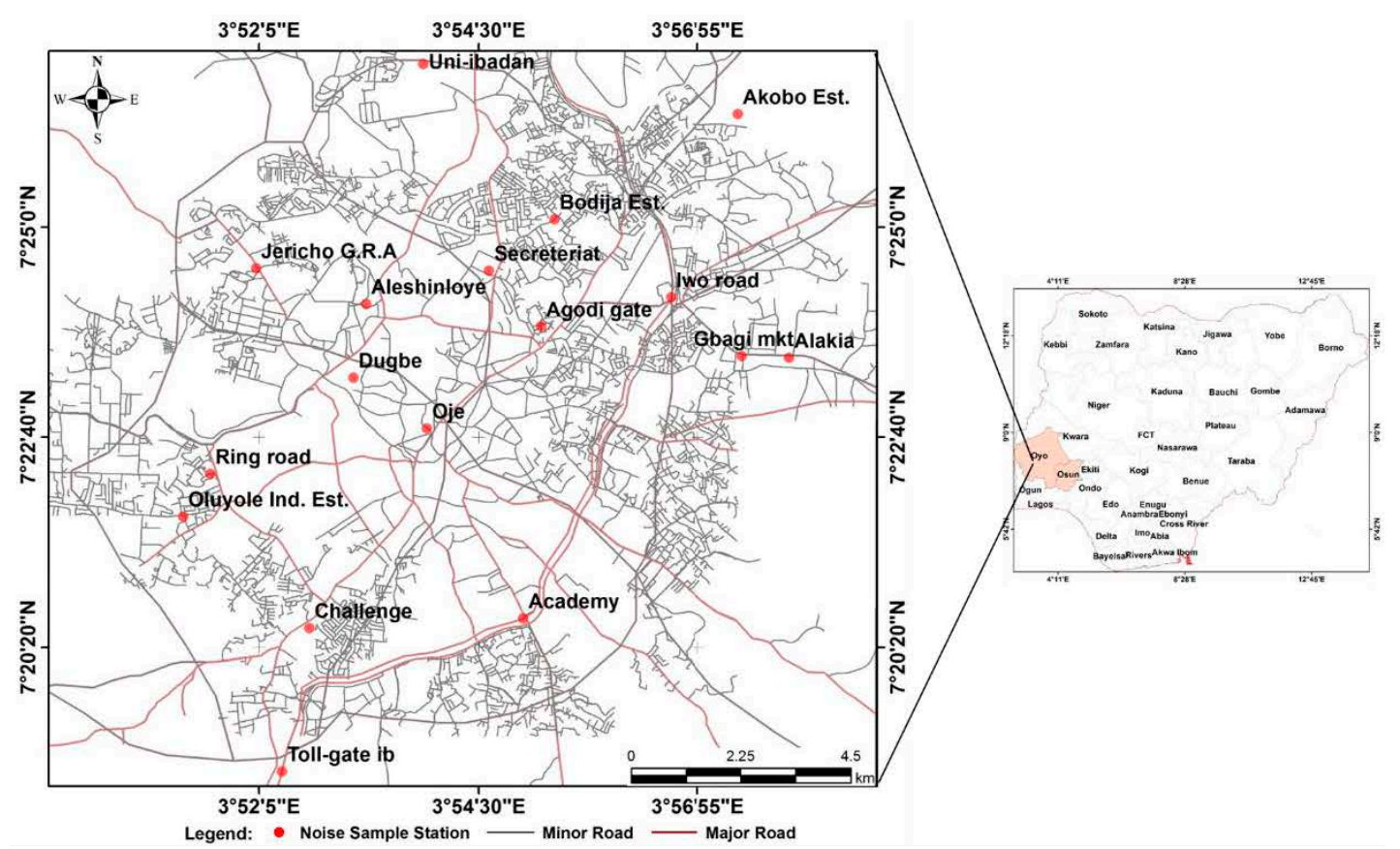

Figure 1. Map of Ibadan Metropolis. 


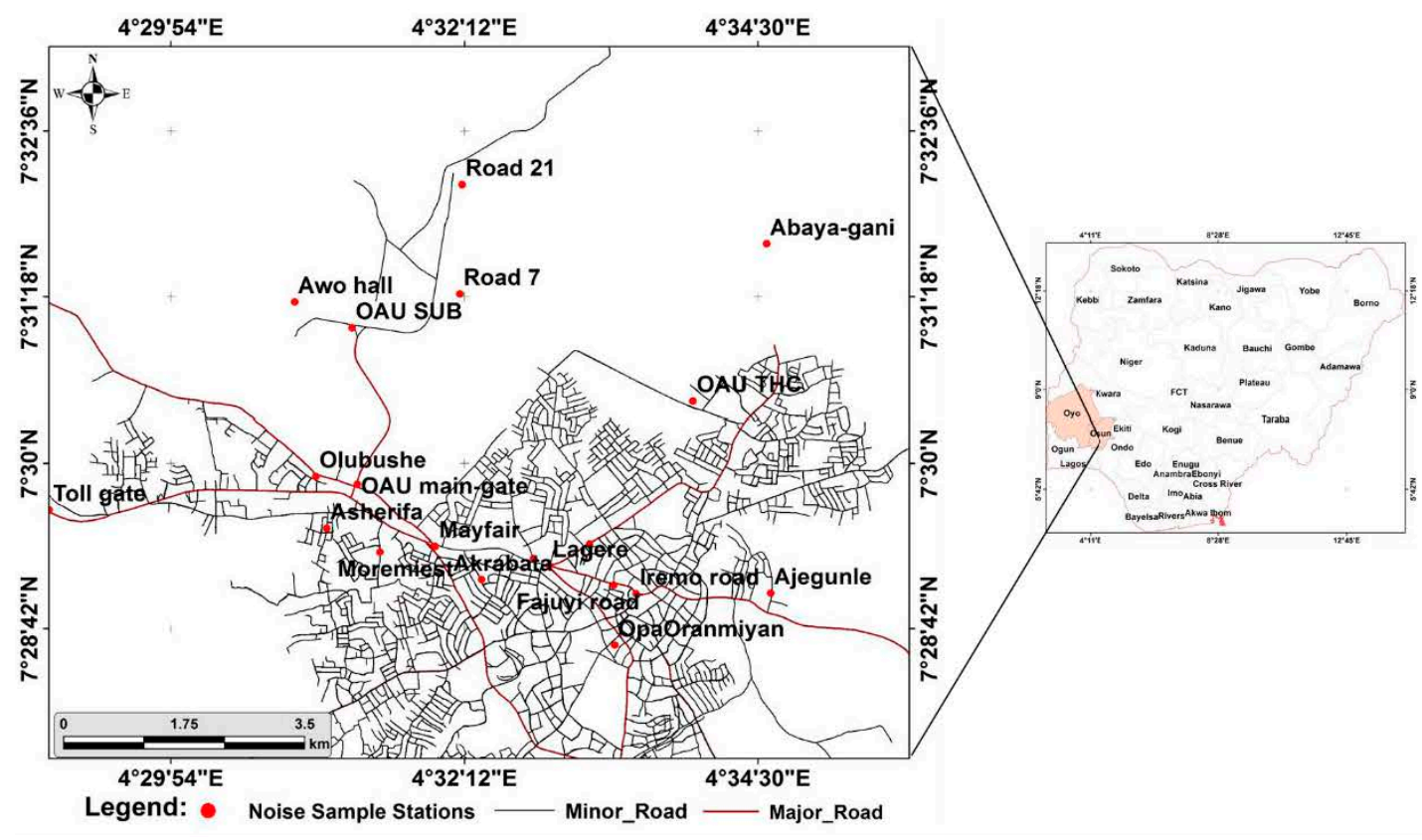

Figure 2. Map of Ile-Ife.

\subsection{Data Analysis}

Descriptive statistical analyses, including averages and simple charts, were used to summarize the data, while inferential statistics in the form of a one-way analysis of variance (ANOVA) were carried out to evaluate the effect of land-use types on noise. The fixed factor for the ANOVA was land use with four categories; residential, educational, transportation, and commercial, while noise was the dependent variable. The assumption of homogeneity of variance was performed using Levene's Test, while Tukey's HSD was used for the pair-wise post hoc test.

Table 2. Noise sensitivity zones [81].

\begin{tabular}{cc}
\hline $\mathbf{d B}(\mathbf{A})$ & Sensitivity \\
\hline $55-<60$ & Risky \\
$60-<65$ & Moderately Risk \\
$65-<70$ & Highly risky \\
$70-<75$ & Dangerous \\
$75-<80$ & Highly dangerous \\
$>80$ & Extremely dangerous \\
\hline
\end{tabular}

\section{Results and Discussion}

\subsection{Detailed Noise Levels in Ibadan and Ile-Ife}

\subsubsection{Characterization of Noise Levels in Ibadan and Ile-Ife Cities}

Table 3 shows the recorded noise level of sampled locations in Ibadan in the morning, afternoon, and evening. The mean, average minimum, and average maximum noise levels for the morning rush hour were $74.01 \mathrm{~dB}(\mathrm{~A}), 68.3 \mathrm{~dB}(\mathrm{~A})$, and $78.35 \mathrm{~dB}(\mathrm{~A})$; the afternoon measurements were $72.31 \mathrm{~dB}(\mathrm{~A}), 65.6 \mathrm{~dB}(\mathrm{~A})$ and 
$77.1 \mathrm{~dB}(\mathrm{~A})$; and the evening observations were $73.23 \mathrm{~dB}(\mathrm{~A}), 65.15 \mathrm{~dB}(\mathrm{~A})$, and $79.55 \mathrm{~dB}(\mathrm{~A})$, respectively. The noise level readings for Ibadan show that the highest noise levels were recorded on Fridays, followed by Mondays, while the least noise levels were recorded on Sundays (Figure 3).

Table 3. Noise levels in Ibadan for morning, afternoon and evening.

\begin{tabular}{ccccccccccc}
\hline \multirow{2}{*}{ Location } & \multicolumn{3}{c}{ Morning } & \multicolumn{3}{c}{ Afternoon } & \multicolumn{3}{c}{ Evening } \\
\cline { 2 - 10 } & Mean & Min. & Max. & Mean & Min. & Max. & Mean & Min. & Max. \\
\hline Academy & 78.2 & 74 & 82 & 75.8 & 70 & 82 & 77.2 & 66 & 83 \\
Agodi Gate & 80.4 & 75 & 86 & 80 & 73 & 88 & 79 & 75 & 83 \\
Akobo Est & 64 & 59 & 68 & 62.2 & 60 & 64 & 65.2 & 61 & 70 \\
Alakia & 70.8 & 65 & 79 & 71.4 & 68 & 76 & 73.6 & 61 & 80 \\
Aleshinloye & 77 & 68 & 81 & 72 & 61 & 77 & 74.8 & 63 & 81 \\
Bodija est & 68.4 & 65 & 72 & 63 & 60 & 67 & 64.6 & 59 & 68 \\
Challenge & 76.4 & 70 & 80 & 71.4 & 67 & 75 & 71.8 & 65 & 81 \\
Dugbe & 71.8 & 66 & 75 & 70.6 & 64 & 75 & 69.8 & 64 & 76 \\
Gbagi Mkt & 80.6 & 73 & 86 & 80.6 & 68 & 86 & 80.8 & 77 & 85 \\
Iwo Road & 84.8 & 78 & 89 & 83.8 & 76 & 87 & 83.8 & 78 & 89 \\
Iyana Church & 67.6 & 63 & 70 & 66 & 60 & 70 & 69 & 63 & 75 \\
Jericho GRA & 66 & 63 & 68 & 71.4 & 62 & 77 & 70.8 & 64 & 77 \\
Ojoo & 71.8 & 65 & 77 & 66.8 & 64 & 70 & 76.8 & 63 & 85 \\
Oluyole Ind. & 76.6 & 72 & 82 & 76.2 & 67 & 83 & 72 & 65 & 77 \\
Oluyole Res & 64.4 & 61 & 68 & 64.2 & 61 & 68 & 63.4 & 58 & 67 \\
Oje & 81.2 & 72 & 85 & 79 & 64 & 86 & 77.6 & 70 & 83 \\
Ring road & 72.6 & 70 & 74 & 73.2 & 65 & 77 & 77.4 & 68 & 85 \\
Secretariat & 74.6 & 64 & 82 & 68.8 & 60 & 77 & 72.8 & 61 & 81 \\
Toll-Gate Ib. & 82.6 & 79 & 87 & 81.2 & 75 & 85 & 73.8 & 62 & 80 \\
Uni-Ibadan & 70.4 & 64 & 76 & 68.6 & 67 & 72 & 70.4 & 60 & 85 \\
Average & 74.01 & 68.3 & 78.35 & 72.31 & 65.6 & 77.1 & 73.23 & 65.15 & 79.55 \\
\hline
\end{tabular}

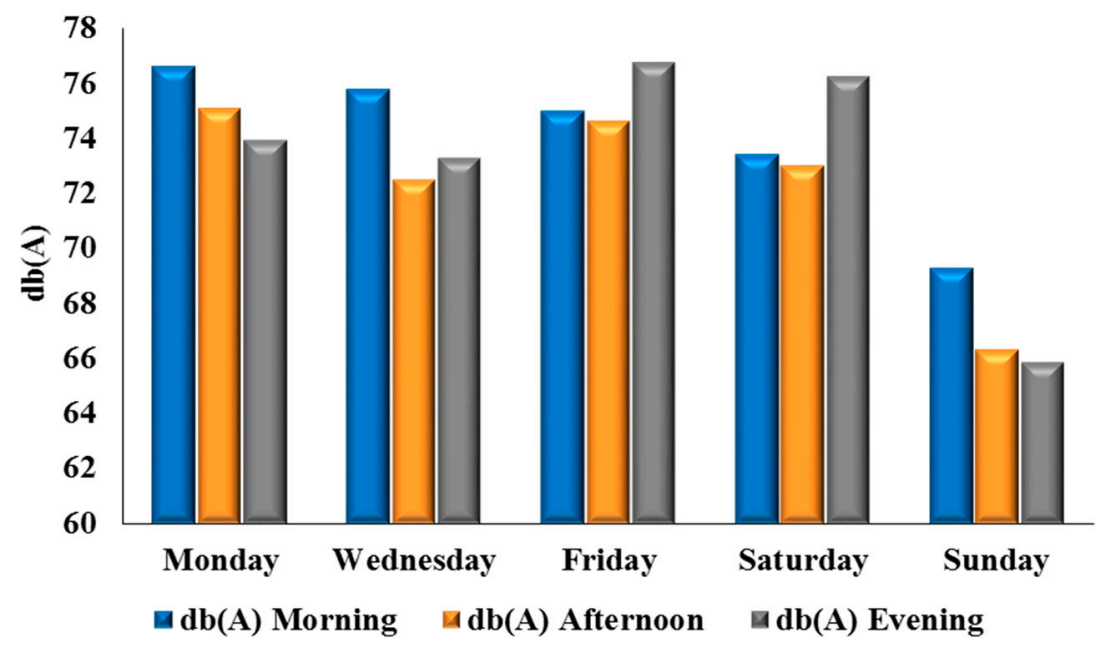

Figure 3. Daily average noise levels in Ibadan. 
Table 4 shows that the mean, average minimum, and average maximum noise for the morning period in Ile-Ife are $68.59 \mathrm{~dB}(\mathrm{~A}), 63.45 \mathrm{~dB}(\mathrm{~A})$, and $73.4 \mathrm{~dB}(\mathrm{~A})$, respectively. For the afternoon period, the readings were $68.91 \mathrm{~dB}(\mathrm{~A}), 61.9 \mathrm{~dB}(\mathrm{~A})$, and $74.9 \mathrm{~dB}(\mathrm{~A})$, respectively, while the mean, average minimum, and average maximum for evening periods were $70.32 \mathrm{~dB}(\mathrm{~A}), 65.55 \mathrm{~dB}(\mathrm{~A})$, and $75 \mathrm{~dB}(\mathrm{~A})$, respectively. The analysis of daily noise levels for the morning, afternoon, and evening periods in Ile-Ife, reveals that Mondays are the noisiest days, both in the mornings and afternoons. The afternoon readings show a slight difference between the average noise levels on Monday mornings (71.4 dB(A)) and Friday afternoon (71.3 dB(A)). However, Sunday evenings in Ile-Ife are also noisy (Figure 4).

Table 4. Noise levels in Ile-Ife for morning, afternoon and evening.

\begin{tabular}{ccccccccccc}
\hline \multirow{2}{*}{ Locations } & \multicolumn{3}{c}{ Morning } & \multicolumn{3}{c}{ Afternoon } & \multicolumn{3}{c}{ Evening } \\
\cline { 2 - 9 } & Mean & Min. & Max. & Mean & Min. & Max. & Mean & Min. & Max. \\
\hline Abaya-gani & 63.2 & 61 & 66 & 61 & 53 & 69 & 57.6 & 53 & 62 \\
Ajegunle & 61.6 & 57 & 67 & 70.6 & 65 & 77 & 70 & 67 & 73 \\
Akrabata & 64.2 & 63 & 66 & 65.8 & 62 & 73 & 70.8 & 67 & 74 \\
Asherifa & 63.4 & 59 & 67 & 70.6 & 64 & 76 & 68.8 & 63 & 76 \\
Awo hall & 64.8 & 60 & 68 & 70.6 & 62 & 76 & 69 & 64 & 73 \\
Eleyele layout & 69 & 63 & 75 & 59.4 & 55 & 64 & 69.2 & 65 & 73 \\
Fajuyi road & 70.2 & 62 & 75 & 67.8 & 57 & 75 & 71.4 & 65 & 76 \\
Iremo road & 79.6 & 70 & 86 & 70.8 & 65 & 75 & 75 & 68 & 83 \\
Lagere & 76.2 & 69 & 81 & 76.8 & 71 & 81 & 79 & 76 & 82 \\
Mayfair & 81.8 & 73 & 87 & 68.2 & 61 & 77 & 68.2 & 59 & 75 \\
OAU main-gate & 67.6 & 63 & 74 & 66 & 60 & 70 & 68.8 & 63 & 73 \\
OAU SUB & 72.2 & 64 & 78 & 71.2 & 61 & 77 & 70.6 & 66 & 78 \\
OAU THC & 70.8 & 68 & 75 & 64.6 & 60 & 70 & 72.2 & 69 & 77 \\
Olubushe & 73.4 & 68 & 79 & 70.4 & 63 & 77 & 67.2 & 63 & 71 \\
Moremi est & 68.2 & 63 & 71 & 64.6 & 61 & 68 & 68.2 & 65 & 73 \\
Opa Oranmiyan & 66 & 64 & 71 & 78.4 & 63 & 86 & 72.4 & 68 & 76 \\
Road 21 & 57.8 & 54 & 62 & 58.8 & 54 & 63 & 62.2 & 58 & 66 \\
Road 7 & 64.6 & 59 & 71 & 67 & 62 & 72 & 69.6 & 63 & 77 \\
Sabo market & 64.8 & 60 & 73 & 78 & 72 & 85 & 80 & 77 & 83 \\
Toll gate & 72.4 & 69 & 76 & 77.6 & 67 & 87 & 76.2 & 72 & 79 \\
Average & 68.59 & 63.5 & 73.4 & 68.9 & 61.9 & 74.9 & 70.3 & 65.6 & 75 \\
\hline
\end{tabular}




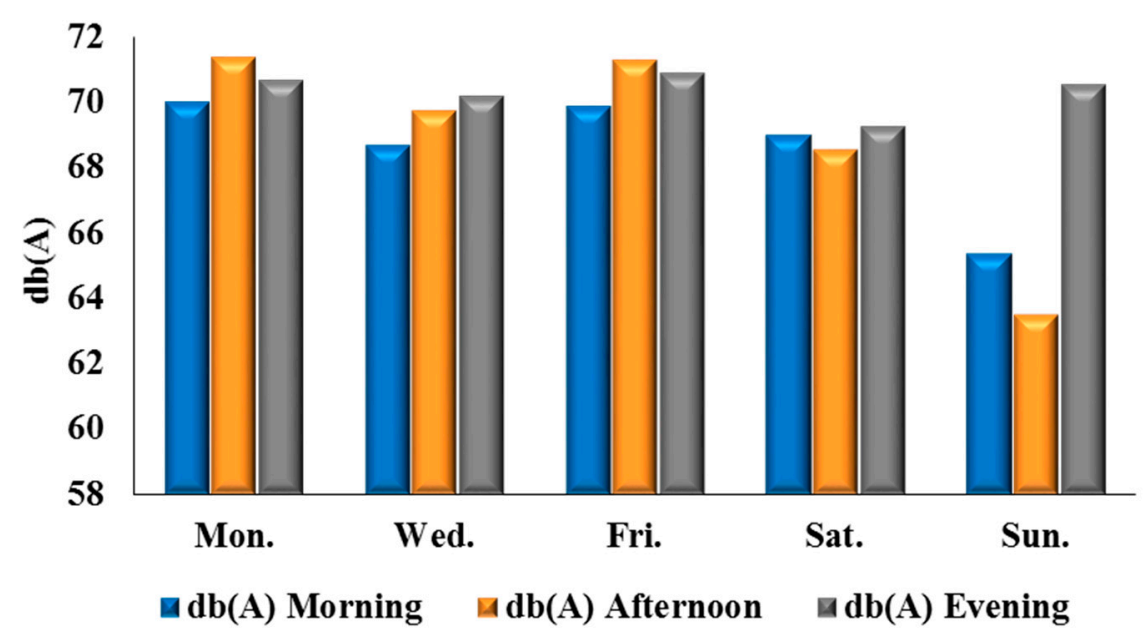

Figure 4. Daily average noise levels in Ile-Ife.

\subsubsection{Spatial Variation of Noise Sensitivity}

Using the US EPA [81] standards on noise sensitivity, the spatial variation of average noise levels in Ibadan and Ile-Ife, for the morning, afternoon, and evening, were mapped to show the level of noise sensitivity associated with the various land uses. The areas around Iwo road, a major transportation hub in the city, fall within the extremely dangerous zone of noise sensitivity ( $80-85 \mathrm{~dB}(\mathrm{~A})$ ) in the mornings, afternoons, and evenings. Places around Toll gate also fall within the extremely dangerous zone in the mornings and afternoons, but reduce to a highly risky level $(65-70 \mathrm{~dB}(\mathrm{~A}))$ in the evenings, which could be attributed to people moving away from the area and into the city center. One striking characteristic of the noise in the Ibadan metropolis is that none of the areas investigated fall below the recommended noise sensitivity level. Places like Akobo and Bodija estates, as well as Jericho GRA and Oluyole residential estate fall within the moderately risky zone of between $60 \mathrm{~dB}(\mathrm{~A})$ and $65 \mathrm{~dB}(\mathrm{~A})$. Noticeable, is the trend in the southeastern part of Ibadan, where noise levels are in the highly dangerous and extremely dangerous, regardless of the time of day.

Figure 5 reveals that $25 \%, 20 \%$, and $10 \%$ of places in Ibadan are within the extremely dangerous zone (ED) in the mornings, afternoons, and evenings, respectively, while a larger percentage of the city is found within dangerous zone (D) of between $70 \mathrm{~dB}(\mathrm{~A})$ and75 $\mathrm{dB}(\mathrm{A})$ in the mornings $(30 \%)$, afternoons (30\%), and evenings (40\%). However, some of the places in Ibadan City are within the moderately risky (MR) range in the mornings, afternoons, and evenings, with the remaining places alternating between highly dangerous zone (HD) and highly risky (HR) at different periods of the day. 


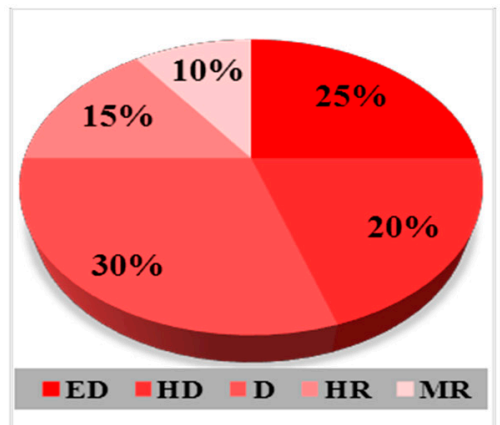

Morning

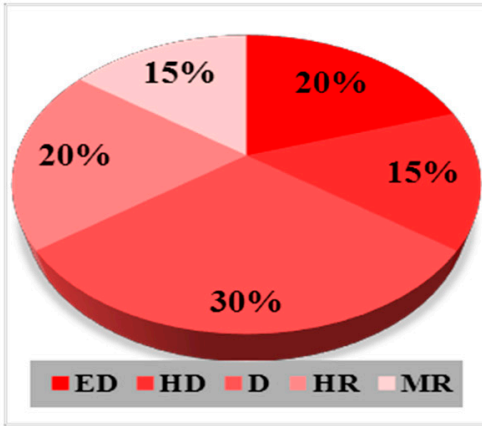

Afternoon

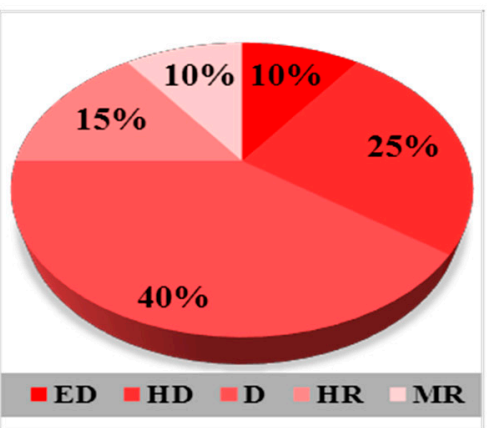

Evening

Figure 5. Percentage of noise distribution in Ibadan.

On the other hand, Figure 6 shows that places around the Mayfair, Lagere, and Sabo areas of Ile-Ife account for the recorded $5 \%$ of urban Ile-Ife that falls within extremely dangerous zone (ED) $(80-85 \mathrm{~dB}(\mathrm{~A}))$ in the mornings and evenings, with the afternoon record showing a slight variation. Additionally, about $20 \%, 30 \%$, and $30 \%$ of places in Ile-Ife fall in the dangerous zone (D) ((70-75 $\mathrm{dB}(\mathrm{A}))$ in the mornings, afternoons, and evenings, respectively. However, it is significant to mention that places around the Obafemi Awolowo University (OAU) staff quarters and Aba'Yagani constitute the 5\%, 10\%, and $5 \%$ of urban Ile-Ife that falls within the risky zone $(55-60 \mathrm{~dB}(\mathrm{~A}))$ in the mornings, afternoons, and evenings, respectively.

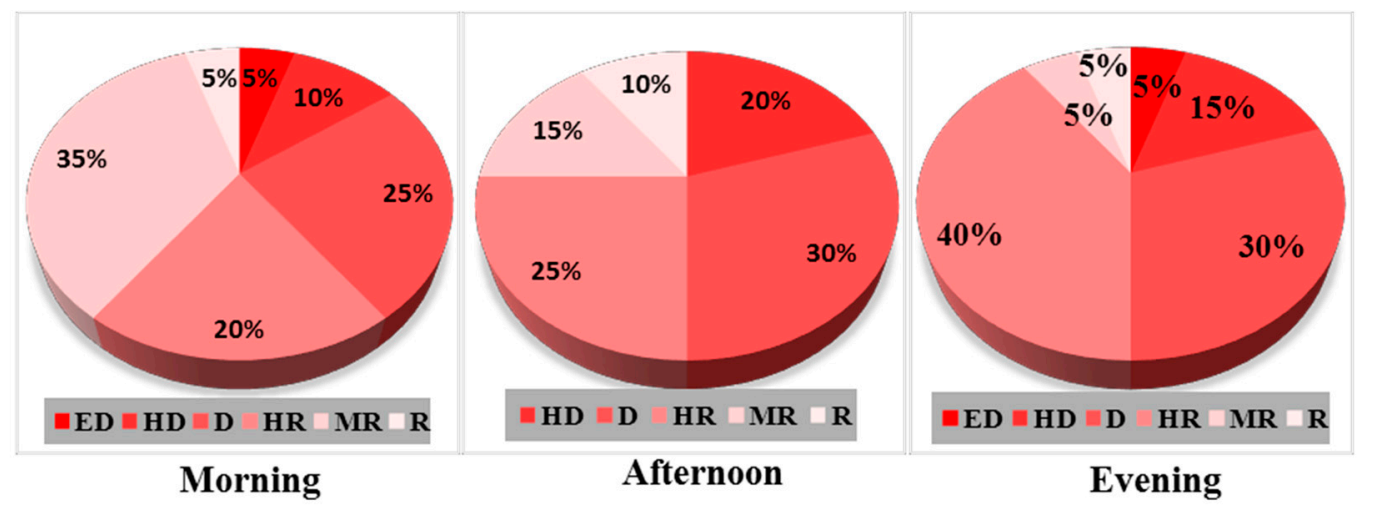

Figure 6. Percentage of noise distribution in Ile-Ife.

\subsection{Comparison of the Average Noise Levels in Ibadan and Ile-Ife}

The overall mean noise level for all the locations on all the days of the week recorded in Ibadan was $73.2 \mathrm{~dB}(\mathrm{~A})$ compared to $69.2 \mathrm{~dB}(\mathrm{~A})$ for Ile-Ife. Figure 7 shows that the mean morning, afternoon, and evening noise levels in Ibadan were $74.3 \mathrm{~dB}(\mathrm{~A}), 72.3 \mathrm{~dB}(\mathrm{~A})$, and $73.1 \mathrm{~dB}(\mathrm{~A})$, which were higher than the average noise levels in Ile-Ife during the same period (68.6 $\mathrm{dB}(\mathrm{A}), 68.8 \mathrm{~dB}(\mathrm{~A})$, and $70.3 \mathrm{~dB}(\mathrm{~A})$ ) respectively. Additionally, the lowest recorded noise for Ibadan is $58 \mathrm{~dB}(\mathrm{~A})$, while that of Ile-Ife is $53 \mathrm{~dB}(\mathrm{~A})$. This signifies that, based on the measurements, the noise pollution in Ibadan is greater than that in Ile-Ife. Noticeable were the mean daily noise levels, which were higher in Ibadan than those obtained in Ile-Ife on all days except for Sunday (Figure 8). 


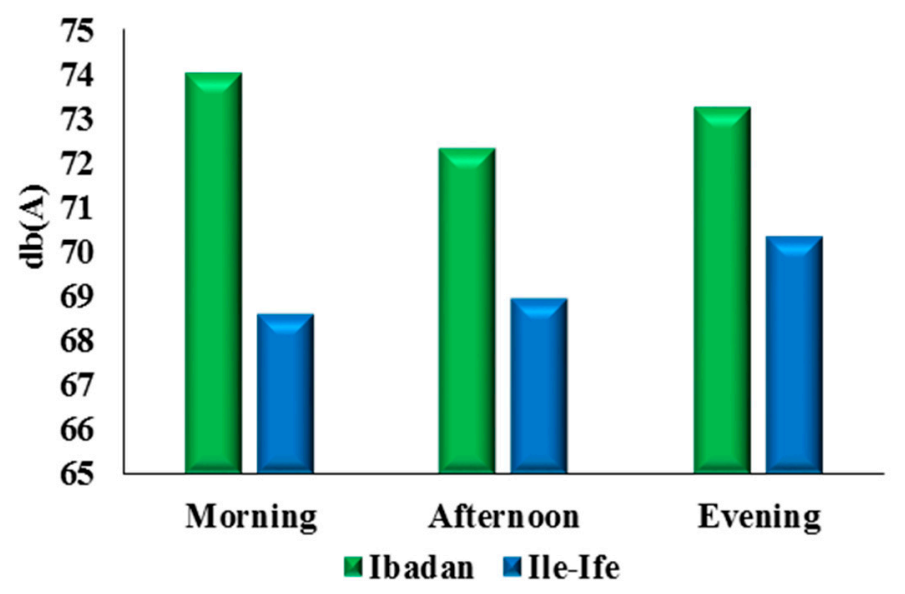

Figure 7. Average daily noise levels in Ibadan and Ile-Ife.

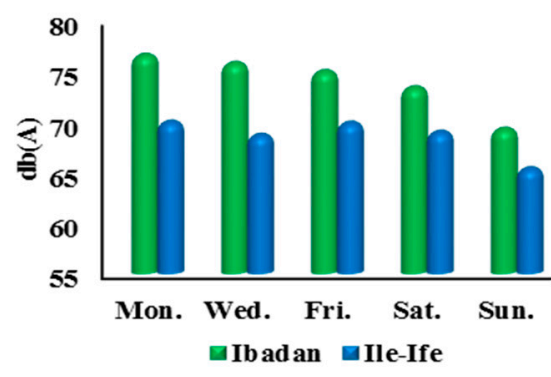

Morning

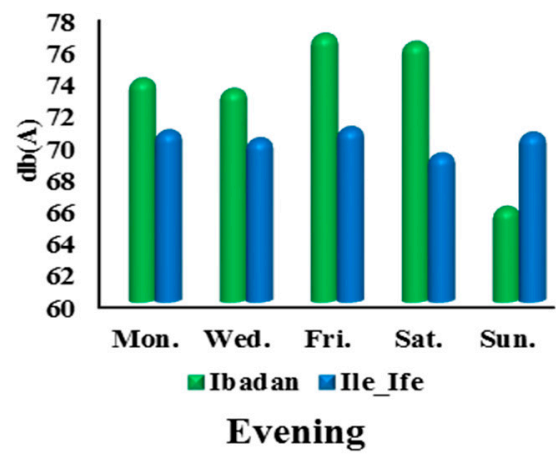

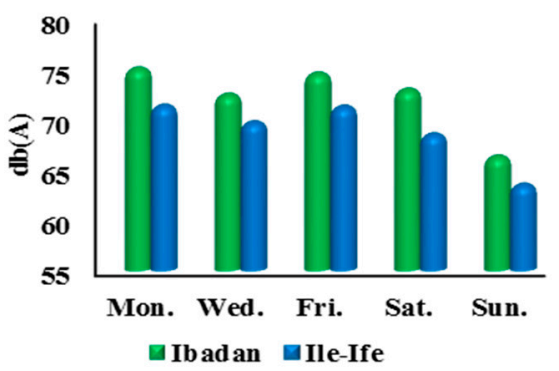

Afternoon

Figure 8. Mean daily noise levels in Ibadan and Ife-Ife.

The noise level readings of both Ibadan and Ile-Ife were also analyzed. The summary of the measurements reveals that $23.5 \%$ of the total noise level recorded for the two cities falls within the highly risky zone (65-69 $\mathrm{dB}(\mathrm{A})$ ), accounting for 141 of the 600 average noise levels recorded. A total of $20.67 \%$ of the average noise level falls within the dangerous zone (70-74 $\mathrm{dB}(\mathrm{A})), 19.67 \%$ within the highly dangerous zone (75-79 $\mathrm{dB}(\mathrm{A})), 16.67 \%$ within medium risk (60-64 $\mathrm{dB}(\mathrm{A})), 10.33$ within highly dangerous ( $80-84 \mathrm{~dB}(\mathrm{~A}))$, and $5.17 \%$ and $3.33 \%$ within extremely dangerous $(80-85 \mathrm{~dB}(\mathrm{~A}))$ and risky (55-59 dB(A)) zones, respectively. A smaller proportion (0.67\%) of all sampled locations in both Ibadan and Ile-Ife falls within the safe zone of less than $55 \mathrm{~dB}(\mathrm{~A})$. These readings translate to $79.3 \%$ of sampled locations in Ibadan and Ile-Ife experiencing noise pollution that is above the recommended noise level (Table 5). 
Table 5. Percentile distribution of the recorded average noise levels.

\begin{tabular}{ccccccccc}
\hline Noise Level Db(A) & Mon. & Wed. & Fri. & Sat. & Sun. & Total & Percentage & Sensitivity \\
\hline $55-<60$ & 2 & 5 & 3 & 5 & 9 & 24 & 4.00 & Risky \\
$60-<65$ & 13 & 12 & 14 & 15 & 46 & 100 & 16.67 & Moderately Risky \\
$65-<70$ & 23 & 37 & 21 & 30 & 30 & 141 & 23.50 & Highly Risky \\
$70-<75$ & 30 & 23 & 29 & 23 & 19 & 124 & 20.67 & Dangerous \\
$75-<80$ & 28 & 23 & 28 & 29 & 10 & 118 & 19.67 & Highly dangerous \\
$>80$ & 24 & 20 & 25 & 18 & 6 & 93 & 15.50 & Extremely dangerous \\
\hline
\end{tabular}

\subsection{Relationship between Land Use and Noise Levels}

The variation in noise level under different dominant land uses for the three periods of the days of the week were analyzed for each city. Land-use-based distributions of noise in the mornings in Ibadan reveal that residential areas had the least average noise levels of $65.1 \mathrm{~dB}(\mathrm{~A}), 66.7 \mathrm{~dB}(\mathrm{~A})$, and $67.6 \mathrm{~dB}(\mathrm{~A})$, for mornings, afternoons, and evening, respectively (Figure 9). This range of values falls within the highly risky zones $(65-70 \mathrm{~dB}(\mathrm{~A}))$, which is more than $10 \mathrm{~dB}(\mathrm{~A})$ above the WHO-recommended daytime residential noise level of $55 \mathrm{~dB}(\mathrm{~A})$. The average morning, afternoon, and evening noise levels for transportation land use are $73 \mathrm{~dB}(\mathrm{~A}), 69.9 \mathrm{~dB}(\mathrm{~A})$, and $71.15 \mathrm{~dB}(\mathrm{~A})$, respectively, falling within the highly dangerous zone (75-80 $\mathrm{dB}(\mathrm{A}))$. The recorded commercial noise levels for morning, afternoon, and evening, $76.77 \mathrm{~dB}(\mathrm{~A}), 73.97 \mathrm{~dB}(\mathrm{~A})$, and $75.94 \mathrm{~dB}(\mathrm{~A})$, are falling mostly within the highly dangerous zone $(75-80 \mathrm{~dB}(\mathrm{~A}))$, more than $20 \mathrm{~dB}(\mathrm{~A})$ higher than the WHO permissible limit of $55 \mathrm{~dB}(\mathrm{~A})$ (day/night). The industrial areas recorded $73.7 \mathrm{~dB}(\mathrm{~A})$ and $73.8 \mathrm{~dB}(\mathrm{~A})$, which were above the WHO recommended noise level at $65 \mathrm{~dB}(\mathrm{~A})$ (day/night). All the noise levels in the different land-use types exceed the respective recommended average noise levels.

The average noise levels across different land uses in Ile-Ife are shown in Figure 10. Results reveals that commercial land use account for $76.77 \mathrm{~dB}(\mathrm{~A}), 73.97 \mathrm{~dB}(\mathrm{~A})$, and $75.94 \mathrm{~dB}(\mathrm{~A})$ for morning, afternoon, and evening, respectively. These readings fall between the dangerous zone of noise sensitivity (70-75 $\mathrm{dB}(\mathrm{A})$ in the afternoons and highly dangerous in the mornings and evenings. These readings exceed the WHO allowable noise limit of $55 \mathrm{~dB}(\mathrm{~A})$ (morning and night) and US EPA $60 \mathrm{~dB}(\mathrm{~A}) /$ morning and $50 \mathrm{~dB}(\mathrm{~A}) /$ night). The average noise levels for transportation land use in Ile-Ife for morning, afternoon, and evening were $78.92 \mathrm{~dB}(\mathrm{~A}), 77.08 \mathrm{~dB}(\mathrm{~A})$, and $76.8 \mathrm{~dB}(\mathrm{~A})$, respectively. These values fall in the extremely dangerous zone. Similarly, the residential land use noise levels returned $66.08 \mathrm{~dB}(\mathrm{~A}), 65.36 \mathrm{~dB}(\mathrm{~A})$, and $66.6 \mathrm{~dB}(\mathrm{~A})$ for morning, afternoon, and evening, falling in the highly risky zone (65-70 $\mathrm{dB}(\mathrm{A}))$ and exceeding the WHO standard of $55 \mathrm{~dB}(\mathrm{~A})$ (morning) and $46 \mathrm{~dB}(\mathrm{~A})$ (night). The study by [82] shows similar trend. An interesting range of $70.4 \mathrm{~dB}(\mathrm{~A}), 68.6 \mathrm{~dB}(\mathrm{~A})$, and $70.4 \mathrm{~dB}(\mathrm{~A})$ was recorded for educational land use in Ile-Ife. This falls in the high risk zone $(65-70 \mathrm{~dB}(\mathrm{~A}))$ and more than $20 \mathrm{~dB}(\mathrm{~A})$ above the recommended WHO standard of $46 \mathrm{~dB}(\mathrm{~A})$ for day and $36 \mathrm{~dB}(\mathrm{~A})$ (night) for silent zone. Land use types in Ibadan and Ile-Ife were compared to the WHO standards for day (morning, afternoon) and night (evening). As shown in Figure 11, all land-use types considered, in both Ibadan and Ile-Ife, exceed the WHO noise standards. 


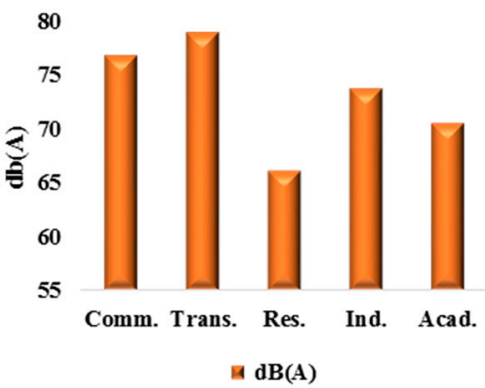

Morning

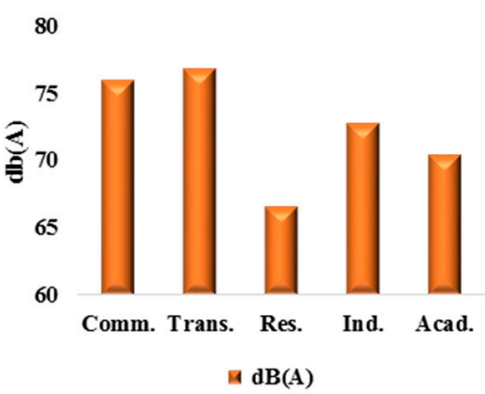

Evening

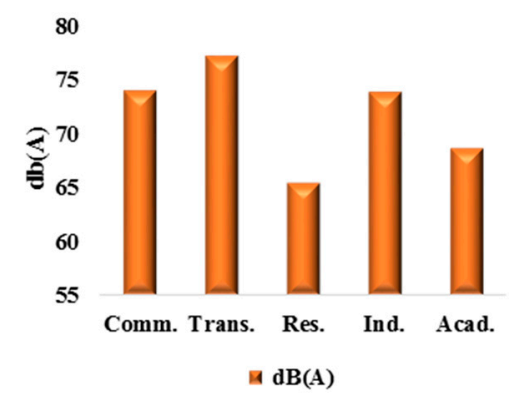

Afternoon

Figure 9. Average noise levels and land use in Ibadan.
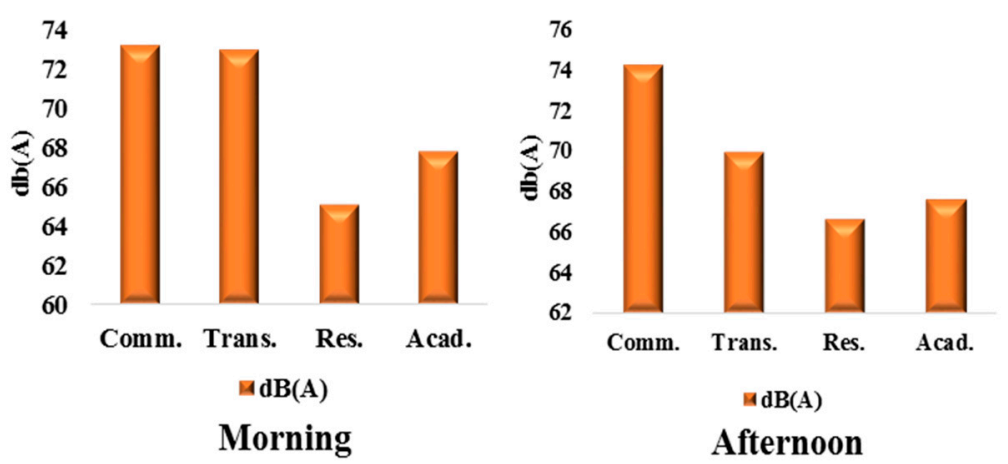

80

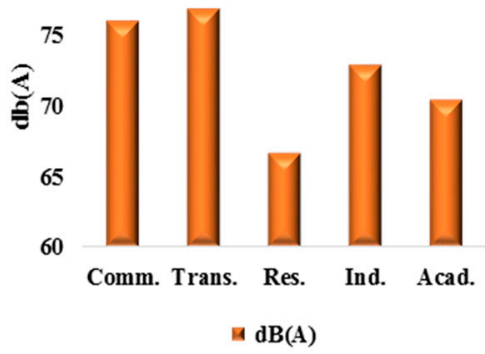

Evening

Figure 10. Average noise levels and land use in Ile-Ife. 

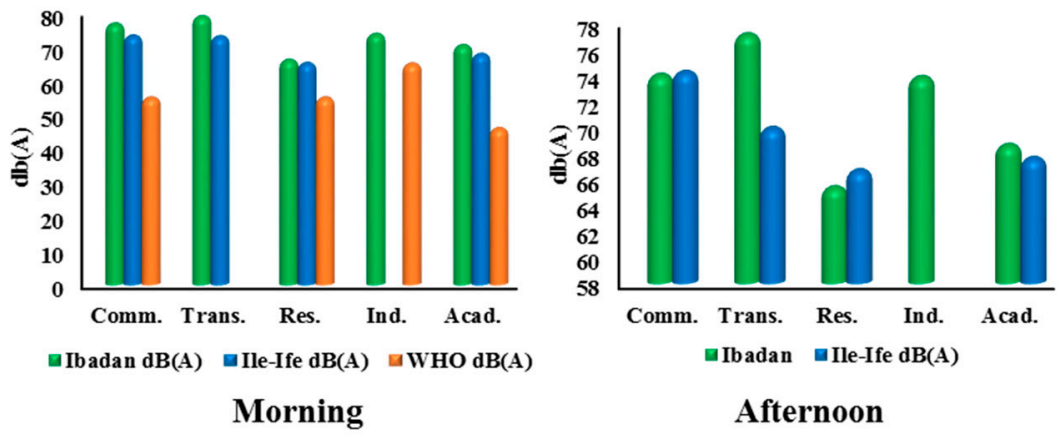

Afternoon

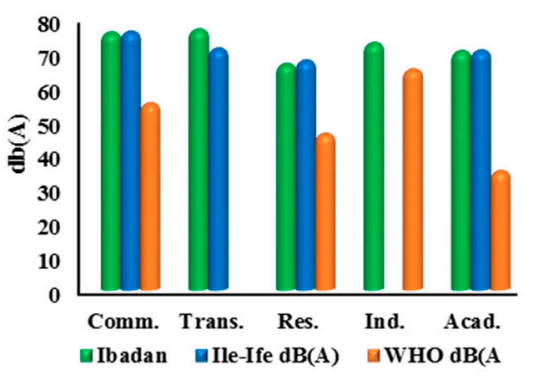

Evening

Figure 11. Comparative mean of daily noise levels across land uses in Ibadan and Ife-Ife.

To evaluate the effect of land use types on noise, a one-way analysis of variance (ANOVA) was conducted with the fixed factor being land use, with four categories; residential, educational, transportation, and commercial, while noise was the dependent variable. The assumption of homogeneity of variance was first tested and the result were found tenable using Levene's Test, $\mathrm{F}(3,34)=1.50$, $p=0.245$. The results of the ANOVA test, shown in Table 6 reveal a statistically significant relationship $\mathrm{F}(3,34)=15.13, p=0.000$. Additionally, the Tukey's HSD (Table 7) pair-wise follow-up test revealed that noise levels between residential and transportation land use types $(\mathrm{M}=-25.32, \mathrm{SD}=4.80)$ are statistically significant, as with noise levels between residential and commercial land-use types $(\mathrm{M}=-26.33, \mathrm{SD}=4.52)$. However, the differences in noise levels between other groups are not statistically significantly.

Table 6. Analysis of variance of noise levels across land use.

\begin{tabular}{cccccc}
\hline \multicolumn{7}{c}{ ANOVA } & & Sig. \\
\hline & Sum of Squares & Df & Mean Square & F & .000 \\
Between Groups & 5874.801 & 3 & 1958.267 & 15.132 &. \\
Within Groups & 4400.151 & 34 & 129.416 & & \\
Total & 10274.953 & 37 & & & \\
\hline
\end{tabular}

$\mathrm{Df}=$ degree of freedom; Sig. = level of Significance. 
Table 7. Tukey's HBD Multiple comparison between noise levels across land use types Dependent Variable: Noise, Tukey HSD.

\begin{tabular}{cccc}
\hline \multirow{2}{*}{ (I) Land Use (J) Land Use } & Mean Difference & \multirow{2}{*}{ Std. Error } \\
\cline { 3 - 4 } & Educational & -7.92000 & 7.19489 \\
Residential & $-25.32000 *$ & 4.79660 \\
& Transportation & $-26.33212 *$ & 4.51585 \\
\hline \multirow{3}{*}{ Educational } & Commercial & 7.92000 & 7.19489 \\
& Residential & -17.40000 & 7.58408 \\
& Transportation & -18.41212 & 7.40971 \\
\hline \multirow{3}{*}{ Transportation } & Commercial & $25.32000 *$ & 4.79660 \\
& Residential & 17.40000 & 7.58408 \\
& Educational & -1.01212 & 5.11319 \\
\hline \multirow{3}{*}{ Commercial } & Commercial & $26.33212 *$ & 4.51585 \\
& Residential & 18.41212 & 7.40971 \\
& Educational & 1.01212 & 5.11319 \\
\hline
\end{tabular}

Excessive noise is a major environmental complaint in urban areas emanating from different land uses. Noise disturbance significantly impacts many areas with a high population density and affects the inhabitants in their daily life, sleep, work, and study. The results in the preceding sections detail the compilation and statistical calculations of noise levels in Ibadan and Ile-Ife, as well as the comparative breakdown of noise across both cities. The emergence of Monday and Friday as the noisiest days of the week, in both Ibadan (Figure 3) and Ile-Ife (Figure 4), could be attributed to the socio-economic practices of the inhabitant of the cities. The increasing noise generated by the various urban land uses, especially those relating to transportation and commercial activities in Nigeria cities, and by extension in developing countries, is a cause for concern. The average noise level in the residential, commercial, and transportation areas of Ibadan were $65.2 \mathrm{~dB}(\mathrm{~A}), 75.9 \mathrm{~dB}(\mathrm{~A})$, and $75.9 \mathrm{~dB}(\mathrm{~A})$ (Figure 9), respectively, while those of Ife were $65.5 \mathrm{~dB}(\mathrm{~A})$ and $73.6 \mathrm{~dB}(\mathrm{~A})$ (Figure 10), which exceed the allowable WHO noise level limits. These computed noise levels, vis-à-vis explained violations observed in the cities of Ibadan and Ile-Ife, are similar to those reported in other studies [83-87].

Noise levels can be influenced by time of day and day of the week. For instance, Monday marks the beginning of many economic activities, and a high inflow of people who left the city for the weekend, while Friday is mainly characterized by the increase of vehicular traffic and mass movement out of the cities by travellers. Hence, results revealed that Mondays and Fridays recorded the highest morning and evening noise in Ibadan and Ile-Ife. The emergence of Sunday as the quietest day of the week in both cities can be explained by the socio-cultural activities of the people in the cities. Traditionally, Sundays are usually devoid of many socio-economic functions, except for religious activities, which in most cases are solemn and take about three to four hours for many places of worship in Ibadan and Ile-Ife. In the light of this, vehicular traffic and movements are always limited, as people often remain indoors to rest from all socio-economic engagements of the previous week and to prepare for the incoming week. 
The overall results on noise pollution in different zones of Ibadan and Ile-Ife cities indicates that the noise pressure levels were highly variable and were the manifestation of diverse man-made activities in these zones. However, all readings in this respect are higher than the recommended values and suggest that many of the dominant activities on these land uses are carried out with no respect for the environment. This further shows possible link between the socio-cultural orientation of the people and their use of the environment. Additionally, the mean noise levels calculated for both Ibadan and Ile-Ife was $71.3 \mathrm{~dB}(\mathrm{~A})$ and this exhibits similar characteristics with results obtained by [72].

The test of the relationship between noise and land-use types shows that noise in typical urban cities in Nigeria is greatly influenced by prevailing land-use types, and that there is a marked difference in noise levels across different land-use types. The implication for the present noise regime in Nigerian urban areas, as typified by those obtained in the in this study, transcends the health consequences of this environmentally-degrading phenomenon. If not properly checked, the noise levels have the potential to affect the re-distribution of people and socio-economic activities within the centers in such a skewed way that they will influence the spread and economic rent of the centers. The increasing rate of development of sprawls and illegal settlements outskirt of many of Nigeria's urban centers attest to this fact.

\section{Limitation to the Study}

Although this study is aimed at comparing urban noise levels under different land use types, the spatial modeling of noise propagation in the study area could have added value to the research. However, the unavailability of, and accessibility to, dedicated noise modeling software did limit the scope of the study. Additionally, constrained by resources, the study could not increase the number of noise sample stations, which in turn could have had considerable statistical significance within the study sites. Similarly, repeated noise observations, especially at different periods of the year, may have ensured a better representation of noise in different seasons, thereby improving the understanding of noise dynamics with respect to urban land use, especially in the typical, fast growing urban centers of developing countries like Nigeria.

\section{Conclusions}

The summary of the total noise levels in both Ibadan and Ile-Ife, which reveals that $79.33 \%$ of sampled locations in both cities exceed the recommended noise levels, thus, suggesting that noise has become a major pollutant in these cities. The study also documented that urban noise is influenced by land use. While noise pollution has been associated with urbanization, living daily with this level of noise in the urban environment could have detrimental physical, physiological, and psychological effects that may, in many cases may, not have an immediate visible manifestation. The present situation of noise pollution in the urban areas Ibadan and Ile-Ife poses severe health risks to the residents. Furthermore, discomfort and irritation caused by the pollution can drastically reduce productivity, both in public service and private sectors. In addition, some areas may soon reach the threshold of pains, leading to permanent loss of hearing and, in some cases, death, in addition to the other not-too-obvious consequences. This can be reversed by, first, assessing existing noise standards in the country against the current level of urban development, and then setting up appropriate and effective monitoring mechanism for proper implementation. The study recommends active noise management strategy at all 
levels of governance in the country and also calls for holistic and realistic land use practices aimed at achieving the millennium development goal of sustainable urban development in Nigerian cities. The study also suggests increased sample size and season-based noise observations for future research in the area of urban noise dynamics, especially in developing countries where limited studies and applications exist.

\section{Acknowledgement}

The authors would like to acknowledge and appreciate the effort of Matti, Samuel Oluwapelumi in the aspects of data collection for this study.

\section{Author Contributions}

David Baloye and Lobina Palamuleni designed the project; David Baloye assisted in the data collection and analysis and drafting of the paper. Lobina Palamuleni proofread and edited the manuscript.

\section{Conflicts of Interest}

The authors declare no conflict of interest.

\section{References}

1. Scott, A.J.; Storper, M. The Nature of Cities: The Scope and Limits of Urban Theory. Int. J. Urban Reg. Res. 2015, 39, 1-15.

2. Glaeser, E.L. A World of Cities: The Causes and Consequences of Urbanization in Poorer Countries. J. Eur. Econ. Assoc. 2014, 12, 1154-1199.

3. Zhao, J.; Zhu, C.; Zhao, S. Comparing the Spatiotemporal Dynamics of Urbanization in Moderately Developed Chinese Cities over the Past Three Decades: Case of Nanjing and Xi'an. J. Urban Plann. Dev. 2014, doi:10.1061/(ASCE)UP.1943-5444.0000251.

4. Solocki, W.; Rosenzweig, C.; Hammer, S.; Mehrotra, S. The urbanization of climate change: Responding to new global challenge from the urban transformation: Health, shelter and climate change. In Wheeler; Stephen, M.; Beatley, T.; Eds.; Routledge: Abingdon, UK, 2013; pp. 107-116.

5. Potter, R.B.; Lloyd-Evans, S. The Cities in the Developing World; Routledge: Abingdon, UK. 2014, pp. 3-15.

6. Jiang, L.; O’Neill, B.C. Global urbanization projections for the Shared Socioeconomic Pathways. Glob. Environ. Change 2015, in press.

7. Chikaraishi, M.; Fujiwara, A.; Kaneko, S.; Poumanyvong, P.; Komatsu, S., Kalugin, A. The moderating effects of urbanization on carbon dioxide emissions: A latent class modeling approach. Technol. Forecast. Soc. 2015, 90, 302-317.

8. Sadorsky, P. The effect of urbanization on $\mathrm{CO}_{2}$ emissions in emerging economies. Energy Economics 2014, 41, 147-153.

9. Al-Mulalia, U.; Ozturkb, L. The effect of energy consumption, urbanization, trade openness, industrial output, and the political stability on the environmental degradation in the MENA (Middle East and North African) region. Energy 2015, 84, 382-389. 
10. Dasgupta, M.; Dasgupta, S.N. Urbanization in India: Revisiting the Energy Aspect and Policy Issues. Available online: http://mpra.ub.uni-muenchen.de/54635/.DOI 10.1007/s11367-011-0377-4 (Accessed on 6 June 2015).

11. Creutzig, C.; Baiocchi, G.; Bierkandt, R.; Pichler, P.; Seto, K.C. Global typology of urban energy use and potentials for an urbanization mitigation wedge. Proc. Natl. Acad. Sci. USA 2014, 112, 20.

12. Lin, B.; Ouyang, X. Energy demand in China: Comparison of characteristics between the US and China in rapid urbanization stage. J. Pure Appl. Sci. 2014, 79, 128-139.

13. Lin, B.B.; Fuller, R.A.; Bush, R.; Gaston, K.J.; Shanahan, D.F. Opportunity or Orientation? Who Uses Urban Parks and Why. PLoS ONE 2014, 9, doi:10.1371/journal.pone.0087422.

14. Tanner, C.J.; Adler, F.R.; Grimm, N.B.; Groffman, P.M.; Levin, S.A.; Munshi-South, J.; Pataki, D.E.; Pavao-Zuckerman, M.; Wilson, W.G. Urban Ecology: Advancing Science and Society. Front Ecol. Environ. 2014, 12, 574-581.

15. Kaushal, S.S.; McDowell, W.H.; Wollheim, W.M. Tracking evolution of urban biogeochemical cycles: Past, present, and future. Biogeochemistry 2014, 121, 1-21.

16. Lin, T.; Gibson, B.; Cui, S.; Yu, C.; Chen, S.; Ye, Z.; Zhu, Y. Managing urban nutrient biogeochemistry for sustainable Urbanization. Environ. Pollut. 2014, 192, 244-250.

17. Liu, C.; Wang, Q.; Zou, C.; Hayashi, Y.; Yasunari, T. Recent trends in nitrogen flows with urbanization in the Shanghai megacity and the effects on the water environment. Environ. Sci. Pollut. Res. 2014, 22, 3431-3440.

18. Aronson, M.F.J.; La Sorte, F.A.; Nilon, C.H.; Katti, M.; Goddard, M.A.; Lepczyk, C.A.; Warren, P.S.; Williams, N.S.G.; Cilliers, S.; Clarkson, B.; et al. A global analysis of the impacts of urbanization on bird and plant diversity reveals key anthropogenic drivers. Proc. R. Soc. 2014, 281, doi:10.1098/rspb.2013.3330.

19. Wang, L.; Lyons, L. Fish and Benthic macroinvertebrate assemblages as indicators of stream degradation in urbanizing watersheds. In Biological Response Signatures: Indicator Patterns Using Aquatic Communities; Simon, T.P. Ed.; CRC Press: Florida, FL, USA, 2003; pp. 227-249.

20. Chen, Y.; Zhou, H.; Zhang, H.; Du, G.; Zhou, J. Urban flood risk warning under rapid urbanization. Environ. Res. 2015, 139, 3-10.

21. Du, S.; Rompaey, A.V.; Shi, P.; Wang, J. A Dual Effect of Urban Expansion on Flood Risk in the Pearl River Delta (China) Revealed by Land-Use Scenarios and Direct Runoff Simulation. Nat. Hazards 2015, 77, 111-128.

22. Khresat, S. Land Degradation Causes and Sustainable Land Management Practices in Southern Jordan. Available online: http://meetingorganizer.copernicus.org/EGU2014/EGU2014-151.pdf (accessed on 27 September 2015).

23. Imbrenda, V.; D’emilio, M.; Lanfredi, M.; Macchiato, M.; Ragosta, M.; Simoniello, T. Indicators for the estimation of vulnerability to land degradation derived from soil compaction and vegetation cover. Eur. J. Soil. Sci. 2014. 65, 907-923.

24. Ferrara, A.; Salvati, L.; Sabbi, A.; Colantoni, A. Soil resources, land cover changes and rural areas: Towards a spatial mismatch? Sci. Total. Environ. 2014, 478, 116-122.

25. Hidayati, D.; Delinom, R.; Abdurachim, A.; Dalimunthe, S.; Haba, J.; Pawitan, H. In Striving to reduce vulnerability: Lessons from the poor community livelihoodsin the jakarta bay facing high risk of rapid urbanization and climate changes, AGU Fall Meeting Abstracts, 2014; p. 0999. 
26. Grossmann, I.; Varnum, M.E.W. Social Structure, Infectious Diseases, Disasters, Secularism, and Cultural Change in America. Psychol. Sci. 2015, 26, 311-324.

27. Hersperger, A.M.; Franscini, M.G.; Kübler, D. Actors, Decisions and Policy Changes in Local Urbanization. Eur. Plan. Stud. 2014, 22, 1301-1319.

28. Gumperz, J.J. Forward: Sociocultural dimensions of language change. In Sociocultural Dimensions of Language Change; Blount, G.; Sanches, M.; Eds.; Academic Press: London, UK, 1977.

29. Sahu, S.; Nair, S.J.; Sharma, P.K. Review on Solid Waste Management Practice in India: A State of Art. Int. J. Innov. Res. Dev. 2014, 3, 261-264.

30. Patil, N.S.; Kumar, V.H.; Bhaskara, A.N. Solid Waste Management and Impact of Landfill Leachate on Groundwater in Hassan City, Karnataka. Int. J. Eng. Res. Technol. 2014, 3, 166-169.

31. Ravindra, K.; Kaur, K.; Mor, S. System Analysis of Municipal Solid Waste Management in Chandigarh and Minimization Practices for Cleaner Emissions. J. Clean Prod. 2014, 89, 251-256.

32. Wiedinmyer, C.; Yokelson, R.J.; Gullett, B.K. Global Emissions of Trace Gases, Particulate Matter, and Hazardous Air Pollutants from Open Burning of Domestic Waste. Environ. Sci. Technol. 2014, 48, 9523-9530.

33. Hill, M.K. Understanding Environmental Pollution: A Primer, 2nd ed.; University Press: Cambridge, UK, 2004; pp. 1-19.

34. Briggs, D. Environmental Pollution and the Global Burden of Disease. Brit. Med. Bull. 2003, $68,1-24$.

35. Templeton, M.R.; Hammoud, A.S.; Butler, A.P.; Braun, L.; Foucher, J.; Grossmann, J.; Boukari, M.; Faye, S.; Jourda, J.P. Nitrate Pollution of Groundwater by Pit Latrines in Developing Countries. AIMS Environ. Sci. 2015, 2, 302-313.

36. Zhang, D.Q.; Jinadasa, K.B.S.N.; Gersberg, R.M.; Liu, Y.; Ng, W.J.; Tan, S.K. Application of Constructed Wetlands for Wastewater Treatment in Developing Countries: A Review of Recent Developments (2000-2013). J. Environ. Manage. 2014, 141, 116-131.

37. Goonetilleke, A.; Yigitcanlar, T.; Ayoko, G.A.; Egodawatta, P. Sustainable Urban Water Environment: Climate, Pollution and Adaptation; Edward Elgar Publishing Limited: Cheltenham, UK, 2014; pp. 1-25.

38. Eze, I.C.; Hemkens, L.G.; Bucher, H.C.; Hoffmann, B.; Schindler, C.; Künzli, N.; Schikowski, T.; Probst-Hensch, N.M. Association between Ambient Air Pollution and Diabetes Mellitus in Europe and North America: Systematic Review and Meta-Analysis. Environ. Health Perspect. 2015, 123, 381-389.

39. Balakrishnan, K. Cohen, A.; Smith, K.R. Addressing the Burden of Disease Attributable to Air Pollution in India: The Need to Integrate across Household and Ambient Air Pollution Exposures. Environ. Health Perspect. 2014, 122, A6-A7.

40. Fleischer, N.L.; Merialdi, M.; van Donkelaar, A.; Vadillo-Ortega, F.; Martin, R.V.; Betran, A.P.; Souza, J.P.; O’Neill, M.S. Outdoor Air Pollution, Preterm Birth, and Low Birth Weight: Analysis of the World Health Organization Global Survey on Maternal and Perinatal Health. Environ. Health Perspect. 2014, 122, 425-430.

41. Zhou, M.; Liu, Y.; Wang, L.; Kuang, X.; Xu, X.; Kan, H. Particulate Air Pollution and Mortality in a Cohort of Chinese Men. Environ. Pollut. 2014, 186, 1-6. 
42. Heeks, R.; Subramanian, L.; Jones, C. Understanding e-Waste Management in Developing Countries: Strategies, Determinants, and Policy Implications in the Indian ICT Sector. Inf. Technol. Dev. 2014, doi:10.1080/02681102.2014.886547.

43. Kristensen, A.K.B.; Thomsen, J.F.; Mikkelsen, F. A review of mercury exposure among artisanal small-scale gold miners in developing countries. Int. Arch. Occup. Environ. Health 2014, 87, 579-590.

44. Usman, A.R.A.; Lee, S.S.; Awad, Y.M.; Lim, K.J.; Yang, J.E.; Ok, Y.S. Soil Pollution Assessment and Identification of Hyperaccumulating Plants in Chromated Copper Arsenate (CCA) Contaminated Sites, Korea. Chemosphere 2012, 87, 872-878.

45. Xie, Y.; Chen, T.; Lei, M.; Yang, J.; Guo, Q.; Song, B.; Zhou, X. Spatial Distribution of Soil Heavy Metal Pollution Estimated by Different Interpolation Methods: Accuracy and Uncertainty Analysis. Chemosphere 2011, 82, 468-476.

46. Job, R.F.S. Noise Sensitivity as a Factor Influencing Human Reaction to Noise. Noise Health 1999, 3, 57-68

47. Pandya, G.H. Assessment of traffic noise and its impact on the community. Int. J. Environ. Stud. 2003, 60, 595-602.

48. Goldsmith, M. Discord: The Story of Noise. Oxford University Press: Oxford, UK, 2012; pp. 1-2.

49. Maisonneuve, N.; Stevens, M.; Niessen, M.E.; Hanappe, P.; Steels, L. In Citizen noise pollution monitoring, Proceedings of the 10th Annual International Conference on Digital Government Research: Social Networks: Making Connections between Citizens, Data and Government; Digital Government Society of North America: California, CA, USA, 2009; pp. 96-103.

50. Anomohanran, O.; Iwegbue, C.M.A.; Oghenerhoro, O.; Egbai, J.C. Investigation of Environmental Noise Pollution Level of Abraka in Delta State, Nigeria. Trends Appl. Sci. Res. 2008, 3, 292-297.

51. Yong, E. City Songbirds Change Their Tune. New Sci. 2008, 197, 33-35.

52. Goines, L.; Hagler, L. Noise Pollution: A Modern Plague. South. Med. J. 2007, 100, 287-294.

53. Tzivian, L.; Winkler, A.; Dlugaj, M.; Schikowski, T.; Vossoughi, M.; Fuks, K.; Weinmayr, G.; Hoffmann, B. Effect of Long-Term Outdoor Air Pollution and Noise on Cognitive and Psychological Functions in Adults. Int. J. Hyg. Environ. Health 2015, 218, 1-11.

54. Singh, A.; Bansal, A.; Goel, S.; Goel, P.K.; Chhikara, P.; Singh, N.K. A Rapid Appraisal of Traffic Policemen about Auditory Effects of Traffic Noise Pollution from Ambala City. Med. J. 2015, 8, 5-12.

55. Bugliarello, G.; Alexandre, A.; Barnes, J.; Wakstein, C. The Impact of Noise Pollution: A Socio-Technological Introduction. Pergamon Press: Oxford, England, 1976; pp. 42-64.

56. Basner, M.; Babisch, W.; Davis, A.; Brink, M.; Clark, C.; Janssen, S.; Stansfeld, S. Auditory and Non-Auditory Effects of Noise on Health. The Lancet 2014, 383, 12-18.

57. Münzel, T.; Gori, T.; Babisch, W.; Basner. M. Cardiovascular Effects of Environmental Noise Exposure. Eur. Heart J. 2014, 35, 829-836.

58. Shahid, M.A.K.; Bashir, H.; Sabir, R.; Awan, M.S. Physiological and Psychological Effects of Noise Pollution on Patients in Different Wards of Rabia Trust Hospital, Faisalabad. PJMMS 2014, 2, 9-11.

59. Luo, J.; Siemers, B.M.; Koselj, K. How Anthropogenic Noise Affects Foraging. Glob. Change Biol. 2015, doi:10.1111/gcb.12997. 
60. Hammer, M.S.; Swinburn, T.K.; Neitzel, R.L. Environmental noise pollution in the United States: Developing an Effective Public Health Response. Environ. Health Perspect. 2014, 122, 115-119.

61. Rider, C.V.; Boekelheide, K.; Catlin, N.; Gordon, C.J.; Morata, T.; Selgrade, M.K.; Sexton, K.; Simmons, J.E. Cumulative Risk: Toxicity and Interactions of Physical and Chemical Stressors. Toxicol. Sci. 2014. 137, 3-11.

62. Levak, K.; Horvat, M.; Domitrović, H. In Effects of noise on humans, ELMAR, 2008. 50th ed.; International Symposium, 2008; IEEE: pp. 333-336.

63. WHO. United Nations Road Safety Collaboration: A Handbook of Partner Profiles; World Health Organization: Geneva, Switzerland, 2005.

64. Berglund, B.; Lindvall, T. Community noise, In Center for Sensory Research; Stockholm University and Karolinska Institute: Stockholm, Swenden, 1995.

65. Chauhan, A.; Pande, K.K. Study of Noise Level in Different Zones of Dehradun City, Uttarahand. Report Opinion 2010, 2, 65-68.

66. WHO. Night Noise Guidelines for Europe. Available online: http://www.euro.who.int/_data/ assets/pdf_file/0017/43316/E92845.pdf (accessed on the 17 July 2015).

67. Larkin, B. Techniques of Inattention: The Mediality of Loudspeakers in Nigeria. Anthropol. $Q$. 2014, 87, 989-1015.

68. Eze, C.L.; Akari, J.; Ogunbona, T. An Investigation of the Impact of Aircraft Noise from Osubi Airstrip, Warri, Delta State, Nigeria, on the Surrounding Residential Environment. J. Emerg. Trends Eng. Appl. Sci. 2014, 5, 291-294.

69. Sonibare, J.A.; Adeniran, J.A.; Fakinle, B.S.; Latinwo, I.O.; Jimoda, L.A.; Olu-Arotiowa, O.A. Ambient Noise from Off-Grid Diesel Engines Electric Power Generators in an Urban Environment. Manag. Environ. Q. Int. J. 2014, 25, 186-199.

70. Ibrahim, I.B.; Aremu, A.S.; Ajao, K.R.; Ojelabi, A.T. Evaluation of Noise Pollution and Effects on Workers during Wheat Processing. J. Appl. Sci. Environ. Manag. 2014, 18, 599-601.

71. Awa, T.P.; Olusegun, A.J. Environmental Pollution in Urban Market: The Case of Bodija Market Ibadan, Nigeria. Dev. Ctry. Stud. 2013, 3, 53-56.

72. Luqman, Y.A., Rowland, A.G.; Zhang, Y.; Umar, O.Z. Work Environment Noise Levels and Risk Locations in Two Selected Commercial Areas in Ibadan, Nigeria. Available online: http://www. medicalresearchjournal.org/index.php/GJMR/article/view/505 (accessed on 27 September 2015).

73. Oyedepo, O.J., Ekom, R.I.; Ajala, K.A. Analysis of Traffic Noise along Oyemekun-Oba-Adesida Road Akure Ondo State Nigeria. Int. J. Eng. Res. Appl. 2013, 6, 72-77.

74. Afolabi, A.; Francis, F.A.; Adejompo, F. Assessment of Health and Environmental Challenges of Cement Factory on Ewekoro Community Residents, Ogun State, Nigeria. Am. J. Hum. Ecol. 2012, $1,51-57$.

75. Aderamo, A.J. Urban Transportation Problems and Challenges in Nigeria: A Planner's View. Prime Res. Educ. 2012, 2, 198-203.

76. Asuquo, U.; Onuu, M.; Asuquo, A. Effects of Exposure to Loud Noise on the Hearing of the Residents of Calabar, Nigeria. Can. Acoust. 2012, 40, 50-51.

77. Ladan, M.T. Review of NESREA Act 2006 and Regulations 2009-2011: A New Dawn in Environmental Compliance and Enforcement in Nigeria. Available online: http://www.lead-journal. org/content/12116.pdf (accessed on 27 September 2015). 
78. National Population Commission. Nigeria Census Report, 2006. Available online: http://www. population.gov.ng/images/Priority\%20table\%20Vol\%204.pdf (accessed on 27 September 2015).

79. Ajala, O.A.; Olayiwola, A.M. An Assessment of the Growth of Ile-Ife, Osun State Nigeria, Using Multi-Temporal Imageries. $J G G$ 2013, 5, doi:10.5539/jgg.v5n2p43.

80. Finegold, L.S.; Harris, C.S.; von Gierke, H.E. Community Annoyance and Sleep Disturbance: Updated Criteria for Assessment of the Impacts of General Transportation Noise on People. Noise Control. Eng. J. 1994, 42, 25-30.

81. EPA. Pollution, Environmental Issues Terms \& Acronyms 2014. Available online: http://nlquery.epa.gov/epasearch/epasearch?querytext=pollution\&fld=\&areaname=\&areacontacts $=\&$ areasearchurl=\&typeofsearch $=$ epa $\&$ result_template $=2$ col.ftl $\&$ force $=$ no\&filter $=$ sample 4 filt.hts (accessed on 17 July 2015).

82. Oyedepo, O.S.; Saadu, A.A. Evaluation and Analysis of Noise Levels in Ilorin Metropolis, Nigeria. Environ. Monit. Assess. 2010, 160, 563-577.

83. Ugwuanyi, J.U.; Ahemen, I.; Agbendeh, A.A. Assessment of environmental noise in Markurdi metropolis. J. Pure. Appl. Sci. 2005, 6, 134-138

84. Seto, E.Y.W.; Holt, A.; Rivard, T.; Bhatia, R. Spatial Distribution of Traffic Induced Noise Exposures in a US City: An Analytic Tool for Assessing the Health Impacts of Urban Planning Decisions. Int. J. Health Geog. 2007, 6, doi:10.1186/1476-072X-6-24.

85. Oyedepo, S.O.; Saadu, A.A. The changing noise climate of Ilorin metropolis, J. Environ. Eng. Sci. 2008, 25, 797-808.

86. Tsai, K.T.; Lin, M.D.; Chen, Y.-H. Noise mapping in urban environments: A Taiwan Study. Appl. Acoust. 2009, 70, 964-972.

87. King, G.; Roland-Mieszkowski, M.; Jason, T.; Rainham, D.G. Noise Levels Associated with Urban Land Use. J. Urban Health 2012, 89, 1017-1030.

(C) 2015 by the authors; licensee MDPI, Basel, Switzerland. This article is an open access article distributed under the terms and conditions of the Creative Commons Attribution license (http://creativecommons.org/licenses/by/4.0/). 